УДК 140.8:316.77

В.П. Андрущенко, д. філос. н., професор

\section{ФЕНОМЕН ЦІЛІСНОГО СВІТОГЛЯДУ В СУЧАСНІЙ ФІЛОСОФІЇ «НОВОГО ПРОСВІТНИЦТВА»}

Метою публікації є аналіз цілісного світогляду, який відкриває еру інтегрального мислення та має забезпечити розвиток освіти в контексті підготовки людини до життя в умовах нового світового порядку. Центром зазначених роздумів стає вирішення таких нагальних проблем як забезпечення нових світоглядних засад у процесі виховання сучасної молоді, формування комплексу планетарних цінностей та їх практичного значення в життєдіяльності людини й суспільства, а точніше орієнтаційно-регулятивна функція цього світогляду в розвитку освіти. Для виконання означених перспектив потрібні ресурси і час, а головне - люди для яких освіта й виховання є не лише професією, а стає внутрішнім духовним покликанням. Оскільки левова частка таких людей Учителів з великої літери - формується в педагогічному університеті, підтримка вчительської справи має стати одним з головних пріоритетів держави.

Ключові слова: иілісний світогляд, освіта, виховання, людина, цінності, держава.

Андрущенко В.П. Феномен целостного мировоззрения в современой $ф и-$ лософбии «Нового Просвещения».

Целью публикации является анализ целостного мировоззрения, который открывает эру интегрального мышления и может обеспечить развитие образования в контексте подготовки человека к жизни в условиях нового мирового порядка. Центром представленных размышлений становится процесс решения таких насущных проблем как обеспечение новых мировоззренческих основ в процессе воспитания современной молодёжи, формирование комплекса планетарных ценностей и их практического значения в жизнедеятельности человека и общества, а точнее ориентационная и регулятивная функции мировоззрения в развитии образования. Для достижения поставленных перспектив необходимы ресурсы и время, а главное - люди для которых образование и воспитание является не только профессией, а становится внутренним духовным призванием. Поскольку большая часть таких людей - Учителей з большой буквы - формируется в педагогическом университете, поддержка учительского дела должна стать одним з главных приоритетов государства.

Ключевые слова: целостное мировоззрение, образование, воспитание, человек, ценности, государство.

Viktor Andrushchenko. The phenomenon of a holistic worldview in the modern philosophy of "New enlightenment"

The purpose of the publication is to analyze a holistic worldview that opens the era of integrated thinking and must ensure the development of education in the context of preparing a person for life in a new sustainable, open, tolerant and democratic world. The center of these reflections is the solution of such pressing problems as the provision of new world outlooks in the process of educating modern youth, the formation of a set of planetary values and their practical significance in the life of the individual and society, or, more accurately, the orientation-regulative function of this worldview in the development of education. The economy, politics, culture are spheres that require immediate, urgent and radical renewal. The main condition of the salvation of the world is the change in the world view, the return to the wisdom of millennia through the search for the optimal balance, reconciliation and balance between man and nature, rapid development and sta- 
bility between individual and the community, the man and the woman, equality and justice, the state and religion.

The philosophy of the "New Enlightenment" provides the orientation of the person in the educational and informational sphere, helps in solving such issues as the choice of an educational institution and the formation of its own trajectory of the educational process. The need of goals on social values can become the object of cynic and pragmatic manipulations. For fulfilling these prospects resources and time are needed, and what is the most important, people for whom education and upbringing is not only a profession but an internal spiritual vocation. Since the lion's share of such people, the Masters, is formed at the pedagogical university, support for the teaching should become one of the main priorities of the state.

Key words: holistic worldview, education, upbringing, person, values, state.

Актуальність теми дослідження. Чергова доповідь знаменитого Римського клубу, яка була підготовлена Ернстом Вайцзеккером та Андерсом Війкманом, у буквальному розумінні розірвала свідомість світової наукової еліти. Було представлено жорстку критику капіталістичних соціально-економічних засад сучасного суспільства, продемонстровано неприйняття фінансових спекуляцій, відмову від таких напрямків як матеріалізм і редукціонізм, прозвучали заклики до принципово-альтернативних основ сучасної економіки, нового періоду просвітництва, пріоритету холістичного світогляду та планетарної цивілізації - це головні сюжети доповіді, які складають сутнісну канву нового погляду на світовий порядок, його природу, філософські засади та поступ.

Нинішній світ, підкреслюють вчені, знаходиться в небезпеці, його переповнюють процеси, які важко прогнозувати: глобалізація та інформаційна революція, гібридна війна, ескалація напруги, військових дій, нарощення ядерного потенціалу, тероризм, майнове розмежування людей, посилення бідності, екологічна та інформаційна небезпеки, вичерпність ресурсів, корупція... В. Горбулін описав таку ситуацію поняттям «соціальної турбулентності». Солідаризуючись 3 представниками «Римського клубу», вчений розглядає соціальну турбулентність як основну загрозу світу, який стоїть на краю прірви, тому пошук порятунку світу треба шукати негайно.

Постановка проблеми. Економіка, політика, культура - це сфери, які потребують першочергового, невідкладного i радикального оновлення. Основною умовою порятунку світу стає зміна світогляду, повернення до мудрості тисячоліть через пошук оптимального співвідношення, примирення і балансу людини та природи, короткочасовою та довготривалою перспективою, швидкістю та стабільністю, індивідом і колективом, чоловіком і жінкою, рівністю та справедливістю, державою та релігією.

Аналіз останніх досліджень і публікацій. $\mathrm{y}$ вітчизняному філософському просторі ми звертали увагу на роздуми i напрацювання 3 окресленої тематики таких наших авторів як А. Баумейстера, 0. Гомілко, Л. Губерського, В. Кременя, С. Кримського, М. Михальченка, Н. Хамітова, М. Поповича, С. Пролеєва, В. Шинкарука та багатьох інших відомих і видатних українських мислителів.

У свою чергу, члени Римського клубу - біологи Карл-Геран Хеден (Швеція), Акліл Лемм (Ефіопія), філософ-марксист і соціолог Адам Шафф (Польша), політолог Хеліо Джагарібе (Бразилія), сенатори Клейборн Пелл (США), Моріс Ламонтан (Канада), президент Швейцарської конфедерації Нелло Селіо, професор психології Ібаданського університету, генеральний директор Всесвітньої організації 
охорони здоров'я (В003) Адеойе Ламбо (Нігерія), відомий урбаністичними підходами Кензо Танге (Японія) - оприлюднили новий погляд на світ, місце і роль людини в ньому, надали компетентне обгрунтування комплексу першочергових і стратегічних завдань щодо його порятунку і розвитку. Сама постановка завдань не може не викликати поваги, а разом з цим і міркувань над вічними питаннями цивілізаційного поступу людства.

Виділення недосліджених частин загальної проблеми. Центром зазначених роздумів стає вирішення таких нагальних проблем як забезпечення нових світоглядних засад у процесі виховання сучасної людини, формування комплексу планетарних цінностей та їх практичного значення в життєдіяльності людини й суспільства, а точніше функції орієнтації та регуляції цього світогляду в розвитку освіти.

Постановка завдання. Метою зазначеного дослідження $є$ аналіз цілісного світогляду, який відкриває еру інтегрального мислення, має забезпечити розвиток освіти в контексті підготовки людини до життя у новому світі - стійкому, відкритому, толерантному, демократичному, людяному.

Виклад основного матеріалу. Внаслідок розвитку сучасної науки і техніки, бурхливий розвиток інформації та інформаційних систем обумовили потребу в формуванні нової стратегії освіти, науки і культури. Філософія «нового Просвітництва» забезпечує орієнтацію людини в освітньо-інформаційній галузі, допомагає у вирішенні таких питань, як вибір освітнього закладу навчання, як зорієнтуватись у змісті та сформувати власну траєкторію навчального процесу. Причому, якщо зважити на те, що основою основ навчального процесу $є$ його зміст, сенс і спрямованість яка визначається суспільним світоглядом, цілком зрозумі- лою $є$ потреба людини у світоглядній орієнтації в ньому.

Потреба у формуванні цілісного світогляду, який стане провідником освітньої навігації людини у світі знань, інформації, компетенцій та цінностей, $є$ завданням, без виконання якого людина просто потоне в освітньому процесі, втратить свободу, себе як особистість, орієнтацію на суспільні цінності та може стати об'єктом цинічно-прагматичних маніпуляцій. У результаті ми виховуємо людину - компетентну, грамотну, творчу, але орієнтовану виключно на себе, на задоволення власних потреб (або потреб, зрощених маніпулятором), людину відсторонену від загальнолюдських нормативів. Історія дає десятки, а, може, й сотні прикладів становлення людини як «злого генія» для свого народу і для людства. Упередження останнього, мінімізація цього процесу засобами освіти безпосередньо пов'язані з оптимально-організованою світоглядною навігацією людини як суб'єкта навчально-виховного процесу. На жаль, ця тематика ще не стала предметом більшменш розгалужених вітчизняних досліджень, а відтак і необхідної педагогічної практики.

Центральним у словосполученні «світоглядна навігація освіти» $\epsilon$ поняття «світогляду». У філософському розумінні світогляд - це форма духовно-практичного освоєння світу людиною, через яку вона сприймає, осмислює та оцінює навколишню дійсність як світ свого буття й діяльності, визначає сприймає своє місце й призначення в ньому. У світогляд входять узагальнені уявлення про світ і саму людину, про спрямованість ходу подій у світі, про смисл людського життя, історичну долю людства тощо, а також система переконань, принципів та ідеалів. Усі складові елементи світогляду опосередковуються особистим досвідом суб'єкта, здобуваючи завдяки цьому певне емоційне забарвлення і перетворюючись на 


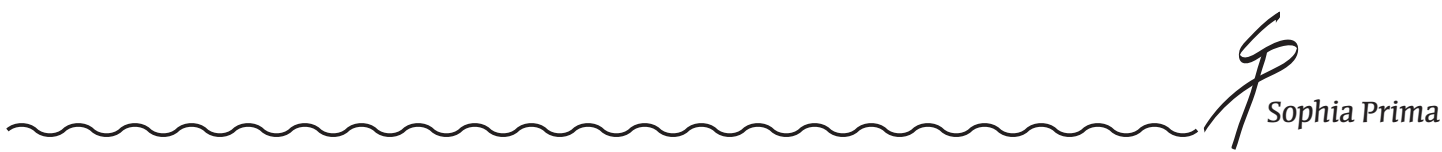

певну персональну установку, що регулює практичну і пізнавальну діяльність людини, виражає ï життєву позицію. Формуючись разом із людською свідомістю на основі матеріальної практики, світогляд духовно реалізує потреби й цілі практичного перетворення світу, виступаючи як його духовно-практичне освоєння, в якому подолання «чужості» світу реалізується створенням образів його іншого, належного і бажаного стану відповідно до ідеалів істини, добра і краси. Зрозуміло, що потреби матеріальної перетворюючої діяльності відображаються у світогляді не безпосередньо, а через систему історично даних суспільних відносин, що надають цим потребам конкретно-практичного змісту.

Історія знає різні типи світоглядів: міфологія, релігія, філософія, наука і мистецтво. Прийнято також розрізняти науковий і ненауковий, тоталітарний і демократичний, релігійний та атеїстичний, побутовий тощо. Кожен із них має свою специфіку, опорні принципи та орієнтації, що складають смислову основу буття. Характерним $\epsilon$ й те, що між цими типами і видами світоглядів різко-розмежувальної лінії не існує, адже базовим співвідношенням, яке узагальнюється світоглядом, $\epsilon$ відношення «людина - світ». Саме такий підхід означає, що різні світогляди проникають один в одного, взаємодіють у системі духовного світу людини й суспільства, періодично переміщуються на перший чи інший план, а відтак виконують різноспрямовану навігаційну функцію.

Візьмемо для прикладу спосіб міркування вченого. За визначенням, він сповідує науковий світогляд, який постає для нього основним навігатором у сучасному світі. Між тим, у випадку досягнення дослідницького результату, який виходить за межі усталеного знання чи практичного досвіду, вчений нерідко апелює до Бога, тобто частково переходить на позиції ре- лігійного світогляду й тішить себе тим, що цю позицію він займає тимчасово, не назавжди. Скажімо, Леонід Каденюк, перший космонавт незалежної України, який поза всяким сумнівом сповідував науковий світогляд, поділяв висновок, який уже зробили чи-мало відомих вчених: «Земля, як і сам Всесвіт, - наслідок діяльності Розуму». Після двотижневого польоту на космічному кораблі «Колумбія» він підтримував слова, які сказав після свого другого польоту в космос американський астронавт Джон Гленн: «Дивитися в ілюмінатор космічного корабля, бачити створене і не вірити в Бога - для мене неможливо» [5, с. 2]. Це не означає, звісно, що дослідник відмовився від наукового світогляду, на якому зрощувалась його особистість. Однак, неможливість осягнення побаченого породила в ньому сумнів, а якщо врахувати поширеність у духовному просторі суспільства релігійного світогляду, вченого охопив сумнів, вихід 3 якого він відшукав саме в релігійному світогляді. Характерно, що більшість видатних вчених світу нерідко попадали в подібну ситуацію й своє коливання між домінантами означених типів світогляду ніяк не заперечували. До речі, Римський клуб вже згаданою доповіддю утверджує нове ставлення до релігії: врівноважене, толерантне, дискурсне. Він дистанціюється від будь-яких інтерпретацій релігії, які підтримують гноблення і насильство, звертає увагу на необхідність виваженого визначення вкладу релігії у розвиток світової цивілізації, пропонує встановити 3 нею конструктивний діалог. Негативнокритичне ставлення до релігії, вважають доповідачі, обірвало зв'язок з мудрістю, накопленою людством.

Доречним є й наступний життєвий приклад: уявимо собі, що людина-атеїст, людина, яка дотримується науково-атеїстичного світогляду, попадає в межову або поза межову ситуацію, виходом з якої може бути лише смерть, що невідворот- 
но наближається. Якою будуть її думки й поведінка: декламування атеїстичних догматів або молитва щодо захисту та порятунку? Практика показує, що більшість людей звернуться до Бога, прочитають молитву, і в цьому немає нічого дивного. Загальнолюдська традиція переконує у тому, що життя дароване Богом і цілком залежить від нього, то хто може знехтувати такою можливістю, щоб вижити?

Характерним $\epsilon$ й те, що в різних життєвих ситуаціях людина може цілком свідомо прийняти й настанови міфологічного світогляду, прийняти окультну практику. Хтось зберігає як важливу для себе ту чи іншу річ, розглядає їі як особистий оберіг; інший вважає, що саме в певні дні йому сприяє успіх; третій дотримується деяких міфологемних традицій, укорінених в духовний простір людини 3 незапам'ятних часів. Надто багато з нас звертається до послуг ворожбитів, приймає окультне знання, намагаються з їх допомогою вилікуватись, передбачити майбутнє, розгадати перепади власної долі. В українському народі, наприклад, у давнину ворожили не тільки відьми, волхви чи ворожбити, але й пересічні люди. Ворожили на різні «теми»: який буде рік, коли на Введіння стільки-то води, а на Юрія трави; скільки на Введіння води, стільки влітку молока; хто перший прийде до хати (буде полазником) на Новий рік; якою буде доля у дівчини і т. п. Найпопулярнішим днем для ворожіння в Україні є ворожіння «на Андрія». Багато 3 цих практик залишилися й на сьогодні. Все це говорить про мімікрію світоглядів, коли поряд 3 домінантним світоглядом уживаються й інші погляди в духовному світі практично кожної особистості.

Отже, навігаційна сила різних світоглядів, звичайно, відрізняється, і який з них вийде переможцем у своєрідному дискурсі, передбачити важко.

Незалежно від типу в своїй основі світогляд має таку структуру: світовідчуття (емоційно-психологічний рівень), світосприйняття (певний досвід формування уявлень про світ з використанням наочних образів), світорозуміння (пізнавально-інтелектуальний рівень). На кожному 3 них навігаційна роль світогляду реалізується по-різному. На рівні світовідчуття людина сприймає (й намагається проникнути в таїнство світу) за допомогою своїх відчуттів. Світ для неї більшою мірою відкривається суб'єктивно не досить чітко і переконливо. Людина створює суб'єктивний образ об’єктивного світу, в якому вона досягає гармонії з цим світом. У своїх відчуттях людина коливається, а тому може використовувати навігаційну технологію цього світогляду з певним застереженням. У той же час, на рівні світосприйняття, яке формує уявлення про світ у вигляді, насамперед, здобутих практично-досвідних наочних образів, навігаційна сила світогляду зростає; вона знаходить своєрідну опору в тих наочних образах, які вдалось сформувати, зафіксувати й розпізнати. Третій рівень світогляду - світорозуміння - дозволяє сформувати інтегроване узагальнення, пронизане розумом уявлення про світ, осягнути його контури, причинно-наслідкові зв'язки, зміст і сенс. Найбільш рельєфно і ефективно навігаційна сила світогляду виявляється у випадку органічної взаємодії світовідчуття, світосприйняття і світорозуміння, яка досягається завдяки науковому типу світогляду.

Науковий світогляд формується як узагальнення наукового знання у його відношенні до людини. У свою чергу, наука - це сфера людської діяльності об'єктивного пізнання світу. Один із перших істориків науки й культури XIX ст., англієць Томас Бокль вбачав у науці «звід узагальнень, достовірність яких такою мірою незаперечна, що вони хоч і можуть бути відсунутими більш високими узагальненнями, проте не можуть бути зруйнованими, іншими словами - таких 


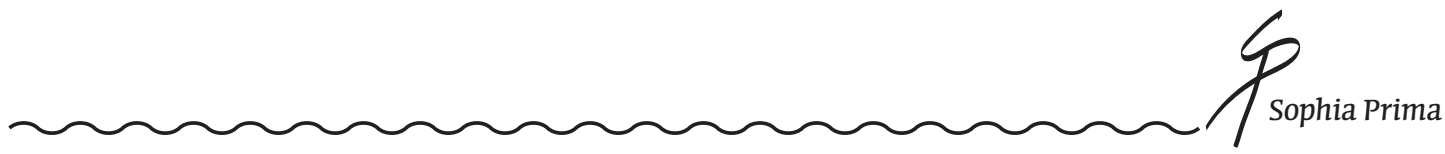

узагальнень, які можуть бути охопленими новими знаннями, але не відкинутими» [4, с. 359]. Саме Боклю належить перше обгрунтування положення про те, що розвиток наукового знання лежить в основі історії цивілізації та $є$ ії̈ визначальним фактором.

Наука, як сфера людської діяльності, спрямована на вироблення й теоретичну систематизацію об'єктивних знань про дійсність. Вона виникає з потреб практики й підпорядкована передусім теоретичному забезпеченню різноманітних форм людської життєдіяльності. Наука відрізняється від таких форм освоєння дійсності, як релігія й мистецтво: якщо релігія апелює до віри, а мистецтво $є$ мисленням в образах, то наука завжди орієнтується на критерії розуму. Вона постає як мислення в поняттях, раціональне відтворення світу. Здавалося б, базований на наукових знаннях світогляд, що формується засобами освіти, може слугувати якісним i єдиним навігатором практичної діяльності людини. Між тим, це не зовсім так. Наука ніколи не $є$ «завершеною книгою», наголошував А. Ейнштейн, кожне нове відкриття ставить нові питання. Більше того, наука може бути як творчою, так і руйнівною силою, заявляв Дж. Бернал [3, с. 117]. Саме тому наукове знання не $\epsilon$ істиною в останній інстанції. I для ефективного здійснення навігаційної функції наука та науковий світогляд потребують не тільки апробації (верифікації, перевірки, підтвердження) практикою, але й доповнення іншими типами світогляду. В сфері людської духовності мають знайти своє місце та функціональне визначення не тільки наукові знання, але й знання з області міфології, релігії, окультизму, астрології тощо. Мова йде про своєрідну конвергенцію типів світогляду, в колі яких людина має вільно орієнтуватись, дискутувати й приймати власне обгрунтоване рішення. Чи варто говорити про те, що такі положення мають пройти че- рез горнило освіти та виховання? А якщо це так, то одним з напрямів реформування галузі поряд із модернізацією змісту навчання, становлення необхідних компетенцій та виховання цінностей має постати завдання формування цілісного світогляду як головного навігатора людини у світі.

Фундаментальною основою цілісного світогляду сьогодні $\epsilon$ наука. Наукове знання - це знання обгрунтоване, доведене, до того ж перевірене практикою. Зрозуміло, перевірене - ще не означає абсолютно вірне. Істина - це процес, у ході якого ті або інші положення міняються місцями. Довіра до науки не може бути абсолютною. В народі кажуть: довіряй, але перевіряй, що потребує постійного дискурсу, повернення до вже укорінених постулатів, здорового сумніву і скепсису. Означену функцію історично перебрала на себе унікальна форма духовно-практичного освоєння світу - філософія.

Філософія, як теоретична основа наукового світогляду, виробляє загальний погляд на світ, місце людини в ньому, досліджує всі можливі спектри і напрями відношення людини до світу. Філософія взяла на себе відповідальність за теоретичне обгрунтування відповідей на такі питання, як мета і сенс життя, щастя і шляхи його досягнення, створення системи життєвих цінностей та ідеалів, вироблення системи ідей, які виражають ставлення людини до соціальної і природної дійсності, визначення вихідних орієнтирів, що обумовлюють програму соціокультурної поведінки людини. Саме тому вона утверджується як інтегративна основа й своєрідний стрижень, який визначає силу і спроможність світоглядної навігації будь-якого типу світогляду в життєвому просторі людини і суспільства. Вивчення філософії є основою у формуванні цілісного світогляду, ширше - духовного світу особистості. Пройшовшись коридорами такої освіти періоду «нового 
Просвітництва», людина утверджується як духовно спроможна, впевнена і захищена особистість. Вона не підвладна ніяким маніпуляціям, має власний погляд, позицію, зрушити з якої може лише завдяки власним сумнівам, роздумам, сподіванням.

Між тим, дехто вільно або ж невільно (віддаючи дань своєрідній моді), намагається якщо й не викинути філософію з навчального процесу, то принаймні обмежити ії локацію серед навчальних дисциплін. Необхідно зауважити, що філософія як любомудріє має приблизно чотирьох тисячолітню історію. Розпочинаючи від прадавніх культур, а, може, й раніше, найбільш освічені, розумні, проникливі уми розмірковували над вічними питаннями буття природи, місця і призначення в ній людини. Визначившись у відповідях, вони делегували їх суспільству, яке за допомогою спеціально підготовлених особистостей - учителів - через освіту передавали їх підростаючим поколінням. Тисячоліттями філософія була сферою повчання від наймудріших до сучасних філософських авторитетів - пронизує й складає стрижневу основу процесу підготовки людини до життя засобами освіти і просвітництва, без яких вона може втратити зв'язок з реальним людським життям, індивідуальними й суспільними інтересами, втратити сенс, а слідом за ним і саму себе як особистість.

Зі зміною епох відходили у вічне старі авторитети, на місце яких приходили нові духовні поводирі людства. Між тим, філософський стрижень їх повчань від найдавніших наставників людства (Конфуцій, Платон і Аристотель) через фундаментальних авторитетів (Кант і Гегель) до сучасних світових інтелектуалів (Гайдеггер, Сартр і Ясперс та ін.) - такі опорні постулати людяності як добро, справедливість і милосердя залишались незмінними. Наповнюючись новим досвідом цивілізації, вони незмінно слугували і слугують нині своєрідними маяками навігаційного процесу освіти. I якщо хтось бажає зруйнувати ï, це слід розпочати 3 обмеження або вилучення філософії з навчального процесу.

Довгий час всі ми, громадяни колишнього СРСР і країн соціалістичної співдружності, були заручниками марксизму - філософії та світогляду класової боротьби, революції і диктатури пролетаріату. Ця філософія пронизувала освіту і виховання, забезпечувала їі навігацію у парадигмі комуністично-орієнтованого світогляду і соціалізації. Здавалося б, вона обгрунтовувала історичне прагнення звільнення людини від експлуатації і насильства, утвердження у суспільстві загальної справедливості і порядку. Між тим, людяністю, справедливістю, милосердям у ній і не пахло! [6]. «Ідеологи комунізму, - писав у свій час М. Бердяєв, - не помітили радикальної суперечності, яка $€$ засадничою стосовно всіх їхніх помислів. Вони прагнули до звільнення особистості, вони оголосили повстання проти всіх вірувань, усіх норм, усіх абстрактних ідей задля цієї емансипації. В ім'я звільнення особистості вони повалили релігію, філософію, мистецтво, мораль, заперечували дух і духовне життя. Проте цим вони пригнічували їі внутрішнє життя, заперечували право особистості на творчість і на духовне збагачення... Емпірична особистість виявилася вилученою із системи прав на творчу повноту життя» [2, с. 46-47]. Він наголошує на цінності марксистського аналізу економічного життя капіталістичного суспільства й водночас стверджує про його хибність як такого, що підпорядковує собі (й собою) весь спектр суперечливих людських стосунків і дій. Економічний детермінізм односпрямованою лінією вивів К. Маркса на історичну місію пролетаріату. Месіанська ідея марксизму, яка, на думку М. Бердяєва, $\epsilon$ виявом «секуляризації давньоєврейської месіанської свідомості», зруйнувала над- 
бання його економічного вчення, адже саме вона постала у вигляді такої домінанти, яка підпорядковує собі все: економіку та куль-туру, людину та мораль, мистецтво й навіть релігію. За висновком М. Бердяєва, К. Маркс створив справжній міф про пролетаріат і саме цим зруйнував науку, підмінивши її вірою та ідеологією. Така ситуація сприяла формуванню світогляду одномірної особистості, дотепно названою в літературі «homo sovetikus».

Відходячи він філософії пролетарської революції та диктатури пролетаріату, українська школа має повернутись до світової філософської думки, яка формує у людини здатність осмислювати світ як єдине ціле, причини змін, що відбуваються в ньому, своє місце і роль у швидкоплинно змінюваному світі. Саме тому розбудову власної системи освіти незалежна Україна розпочала зі звільнення від марксистсько-ленінської світоглядної облуди. Долаючи низку помилок і суперечностей, інтелектуальна еліта держави відшукала той новий філософсько-світоглядний стрижень, якій потрібен нації, народу, державі. У якості останнього поступово утверджується світогляд, який відображає національну і світову гуманістичну ідею, базується на національних та загальнолюдських цінностях, утверджує самоцінність людини, яка вибудовує своє буття на основі добра, справедливості і милосердя. Цей світогляд будується на філософії поваги до людини як особистості, незалежно від її етнічної чи національної належності, кольору шкіри, релігійних уподобань чи статі, примирення людини з природним, людським і божественним світами. В її основі лежить ідея ненасильства, в свій час фундаментально обгрунтована такими мислителями, як М. Ганді, М. Кінг, Г. Сковорода, Л. Толстой, А. Швейцер. Філософія «ставить мислення» й одночасно здійснює його санітарію, зберігаючи від впливу випадковостей, дріб'язкових і очевидних речей.
«Мати гострий, як лезо, аналітичний розум, який дозволяє прояснювати складні речі, проблеми. Насправді дуже мало людей можуть ясно побачити якусь складну річ. Це потребує довгого відточування майстерності й культури мислення. В цьому призначення філософів... Вона (філософія - авт.) привчає нас бачити, що самоочевидностей насправді немає... Філософія - це культура здивування, самоосвіти і критики очевидностей» $[1$, с. 5], - зазначає А. Баумейстер.

Висновки та перспективи подальших досліджень. Формування нового філософського погляду на світ і місце людини в ньому $є$ вагомою цивілізаційною проблемою, участь у вирішенні якої мають взяти представники інтелектуальної еліти всіх народів і країн світу. Аналіз напрацювань, з якими йдуть у цей процес найбільш відомі теоретики, дозволяють запропонувати для обговорення декілька попередніх узагальнень стосовно освітнього аспекту філософії «нового Просвітництва»:

- по-перше, центром нової філософії має бути людина як самоцінність у всій повноті свого творчого ставлення до світу і життя, а головне - в такій же повноті можливостей для власної самореалізації;

- по-друге, нова філософія має базуватись на загальнолюдських цінностях в їх органічному поєднанні з національними пріоритетами;

- по-третє, вона повинна розгортатись як благоговіння перед життям (A. Швейцер), прагнення вічного миру (I. Кант), введення людства у царство вічного спокою і свободи - ноосферну фазу його цивілізаційного поступу (В. Вернадський, Тейяр де Шарден);

- по-четверте, така філософія може бути лише плюралістичною, толерантною, дискурсною, базуватись на свободі творчого мислення, що прямує до істини;

- по-п'яте, вона має витіснити з практичного обігу прагматизм і здирництво, 
тероризм і корупцію, збагачення будьякою ціною, в першу чергу, злочинним чином;

- по-шосте, ця філософія бере на себе відповідальність за формування цілісного світу - відкритого, гармонійного, ненасильницького, за забезпечення стійкого людського розвитку на засадах миру та добробуту.

Таким чином, формування інтегрального мислення та цілісного світогляду, необхідність утвердження яких обгрунтували доповідачі Римського клубу, забезпечать становлення періоду нового Просвітництва, навігацію системи освіти в інтересах людини як особистості, громадянина власної держави і світу, гармонію національних і загальнолюдських пріоритетів, утвердження миру, добробуту і процвітання. Для виконання означених перспектив потрібні ресурси і час, а головне - люди, когорта патріотів-професіоналів, освіта й виховання для яких $\epsilon$ не лише професією, але й внутрішнім духовним покликанням. Й оскільки левова частка таких людей - Учителів з великої літери - формується в педагогічному університеті, підтримка вчительської справи - учителя, школи і педагогічного університету, має стати одним з головних пріоритетів держави. Знання, компетенції, цінності, передані дитині Учителем, $\epsilon$ тими основними складниками, які визначають майбутній життєвий шлях особистості, iї долю. Саме в школі формуються первинні орієнтації, які спонукають учнів до вибору майбутньої професії - космонавта чи науковця, інженера чи дипломата, державотворця чи представника простої професії. Саме в школі викристалізовуються принципи ставлення дитини до природного і людського світу, а головне - закладаються основи гуманізму, справедливості, людяності. Й саме в школі визрівають особистості, які переосмислять і зможуть створити нові філософські засади світобачення, діяльнісно-береж-

ного, трепетного ставлення до нього й тим самим врятують світ, забезпечать подальший розвиток і розквіт цивілізації як головного і неперевершеного продукту Великого Творця.

\section{Література}

1. Баумейстер А. Філософія як аскеза, самоосвіта, здивування [Текст] / А. Баумейстер // День, 23 листопада. - 2016. - № 213. - С. 4-6.

2. Бердяев Н.А. Истоки и смысл русского коммунизма / Н.А. Бердяев. - М.: Наука, 1990. - 224 c.

3. Бернал Дж. Наука и общество / Дж. Бернал. - М., 1953. - 283 с.

4. Бокль Т. История цивилизации в Англии / Т. Бокль. - СПб, 1904. - 402 с.

5. Прокопчук С. [Текст] / С. Прокопчук // Урядовий кур'єр, 15 лютого. - 2018. - С. 2-3.

6. Попович М. Червоне століття / М. Попович. - К. : АртЕк, 2005. - 888 с.

\section{References}

1. Baumeyster A. Filosofiya yak askeza, samoosvita, zdyvuvannya [Tekst] / A. Baumeyster // Den', 23 lystopada. - 2016. - \# 213. - S. 4-6.

2. Berdyaev N.A. Ystoky y smbsl russkoho kommunyzma / N.A. Berdyaev. - M.: Nauka, 1990. - $224 \mathrm{~s}$.

3. Bernal Dzh. Nauka y obshchestvo / Dzh. Bernal. - M., 1953. - 283 s.

4. Bokl' T. Ystoryya tsyvylyzatsyy v Anhlyy / T. Bokl'. - SPb, 1904. - 402 s.

5. Prokopchuk S. [Tekst] / S. Prokopchuk // Uryadovyy kur»yer, 15 lyutoho. - 2018. - S. 2-3.

6. Popovych M. Chervone stolittya / M. Popovych. - K. : ArtEk, 2005. - 888 s.

Надійшла 24.09.2018

Бібліографічний опис для цитування:

Андрущенко В.П. Феномен цілісного світогляду в сучасній філософії «нового Просвітництва» / В.П. Андрущенко // Sophia Prima: діалог вічного повернення. - 2019. - № 1. - C. 11-19. 